

\section{VOL. XIX.-1904.}

THE

\section{JOURNAL OF LARYNGOLOGY,}

\section{RHINOLOGY, AND OTOLOGY;}

AN ANALYTICAL RECORD OF CURRENT LITERATURE

RERATING TO

\section{THE THROAT, NOSE, AND EAR.}

PUBLISHED MONTHLY.

$$
\text { 站 } \mathfrak{v} \mathfrak{n} \mathfrak{d} \mathfrak{a} \mathfrak{n}:
$$

\section{ADLARD AND SON,} BARTHOLOMEW CLOSE. 


\section{THE JOURNAL OF LARYNGOLOGY, RHINOLOGY, ANI) OTOLOGY.}

Founded in 1887 by MORELL MACKENZIE and NORRIS WOLFENDEN.

EDITORS :

JOHN MACINTYRE, M.B., M.Ch., F.R.S.E. ARTHUR SANDFORD, M.D., M.Ch.R.U.I.

DUNDAS GRANT, M.A., M.D., F.R.C.S.Eng.

W. MilligAN, M.D., M.Ch.

Managing SUb-eDitor:

W. JOBSON HORNE, M.A., M.D., B.C.Cantab., M.R.C.P.Lond.

WTH THF CO-OPERATION OF

Drs. Price-Brown (Toronto), Cartaz (Paris), Bryson Delayan (New York), Dodd (Chicago), Donelan (London), Grazzi (Florence),

Guye (Amsterdam), Higguet (Brussels), Middlemass Hunt (Liverpuol),

Hutchison (Brighton), Joal (Paris), Kelly (Glasgow),

Lacoarret (Toulouse), Lichtwitz (Bordeaux), Lieven (Aix-la-chapelle),

Joh n M. Mackenzie (Baltimore), Prof. Massei (Naples), McCall (Bournemouth),

Meyjes (Amsterdam), Mylas (New York), Holagr Mrand (Coyenhagen),

Ponter (St. Louis), SaChs (Hamburg), Satous (Philaltlphia),

Sendziak (Warsau), Sota (Serille), Stclair Thomson (London),

Woods (Dublin), Macleod Yearsley (London), and Ziem (Dantrig.) 


\section{LIST' OF PLA'T'ES.}

Plates I-III.-To Illustrate Dr. W. Milulgan's Paper on “The Etiology and Treatment of Labyrinthine Suppuration " 132, 142

Plates IV-V.-To Illustrate Dr. R. C. Elsworth's Paper on

"Some Points in the Anatomy of the Temporal Bone" 174,176

Portrait of the late Sir Philip Crampton Smyly, M.D.Dub. . 285

Portrait of the late Dr. Camille Miot, of Paris . . 288

Plates I-III.-To Illustrate Dr. E. S. Yonge's Paper on "Some

Observations on the Mode of Origin of Nasal Polypus"

$456,458,460$

Plates I-V.-To Illustrate Professor A. Onodis Paper on

"The Disturbances of Vision and Develophent of Blindness of Nasal Origin Induced by Disease of the Posterior ACCEssory Sinuses" . . . 626, $628,630,632,634$

\section{ILILESTRATITINS IN 'TEST'.}

To Illustrate Mr. Macleod Yearsley's Case of Traumatic ATRESIA . . . . . . . . 361

Figs. 1-5.-To Illustrate Dr. Dundas Grant's Paper on "The Aetiology, Treatmeit, and Prognosis of Innocent Laryn-

GEAL GROWTHS" . . . . . . . $644,646,648$ 
The Index to Volume xviii (pp. $i-x l v$ ) is now ready, and copies will be forwarded post free to all subscribers upon application to the Publishers, ADLARD \& SON, Bartholomew Close, London, E.C.

The price of the Index to Non-Subscribers is Two Shillings.

\section{CONTENTS.}

Special Articles-

Some Points in the Anatomy of the Temporal Bone (with 2 Plates). Fatal Case of Necrosis of the Sphenoidal and Posterior Ethmoidal Cells; Phlebitis of the Cavernous Sinus; Pyrmia.-A. L. Whitenead

ties' Proceedings-

The British Laryngological, Rhinological, and Otological Associatron. Communications by Mayo Collier, W. H. Kelson, Stuart Low, Andrew Wylie, Wyatt Wingrave, Harold Barwell, John

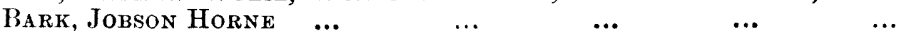

The Laryngological Society of London. Communications by $P$. de Santi, Stclair Thomson, H. Buthin, F. C. Shrubsall, Dundas Grant, Hunter F. Tod, Betham Robinson, Watson Williams, Eugene Yonge, A. H. Burt, Lambert Lack, Furniss Potter, Atwoon Thorne, H. Smurthwajte, H. W. Carson, J. Donelan ..

Abstracts-

Nose AND ACcessory Sinuses.-A Case of Naso-pharyngeal Polypus.Some Observations of the Treatment of Accessory-sinus Disease.Frontal Sinusitis a Cause of Accommodation Paresis.-Cheesy Empyema of the Nasal Accessory Sinuses

Larynx and Trachea. - A Study of the Condition of the Upper Airpassages before and after Intubation of the Larynx; also an Inquiry into the Method of Feeding employed in the Cases.- The Treatment of Laryngeal Tuberculosis.- On a Case of Extraction of a Foreign Body from the Bronchus

... $\quad \cdots \quad$...

Thy RoID.-Goitre at Monte Celio, Rome $\ldots$...
EAr.-On the Substitution of a Gauze Tampon for Stacke's Guard in opening all the Cavities of the Middle Ear.-The Acoustic Function of the Semicircular Canals.-Two Cases of Cholesteatoma of the Middle Ear cured by Intra-aural Treatment.-The Education of Children with Impaired Hearing

Impaired Hearing $\ldots$ at the Site of Injection of Preparations of

Impaired Hearing $\ldots$ at the Site of Injection of Preparations of

Impaired Hearing $\ldots$ at the Site of Injection of Preparations of Mercury.-The Sterilisation of Small Quantities of Surgical Dressings

Diseases of the Ear: A Text-book for Practitioners and Students of Medicine.-E. B. Dench ...

\section{GUIDE TO ADVERTISEMENTS.}

Burroughs, Wellcome and Co. '...

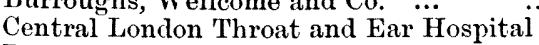
Davidson, $\mathbf{F}$.

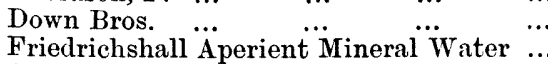
Golden Square Throat Hospital ... $\quad .$. Henry Heil Chemical Co. $\quad \ldots \quad \ldots$ Ingram and Royle, Ltd. $\quad \ldots . \quad \ldots$ Lambert Pharmacal Co. $\quad \cdots \cdot \quad \cdots$ Maw, Son and Sons $\quad \ldots \quad \ldots . \quad \ldots$ Mayer and Meltzer $\ldots$, College and $\dddot{P}_{\text {olyclinic }}$ Parke Davis and Co. Wright, John, and Co. ...

$\begin{array}{lrr} & & \text { pagk } \\ \ldots & \ldots & \text { vi } \\ \ldots & \ldots & \text { ix } \\ \ldots & \ldots & \text { ix } \\ \ldots & \ldots & \text { iii } \\ & & \text { vii } \\ \ldots & . . & \text { x } \\ \ldots & \ldots & \text { viii } \\ \ldots & & \text { vii } \\ \ldots & \ldots & \text { ii } \\ \ldots & . . & \text { ii } \\ \ldots & \ldots & \text { xi, xii } \\ \ldots & \ldots & \text { viii } \\ \text { Front page of cover }\end{array}$




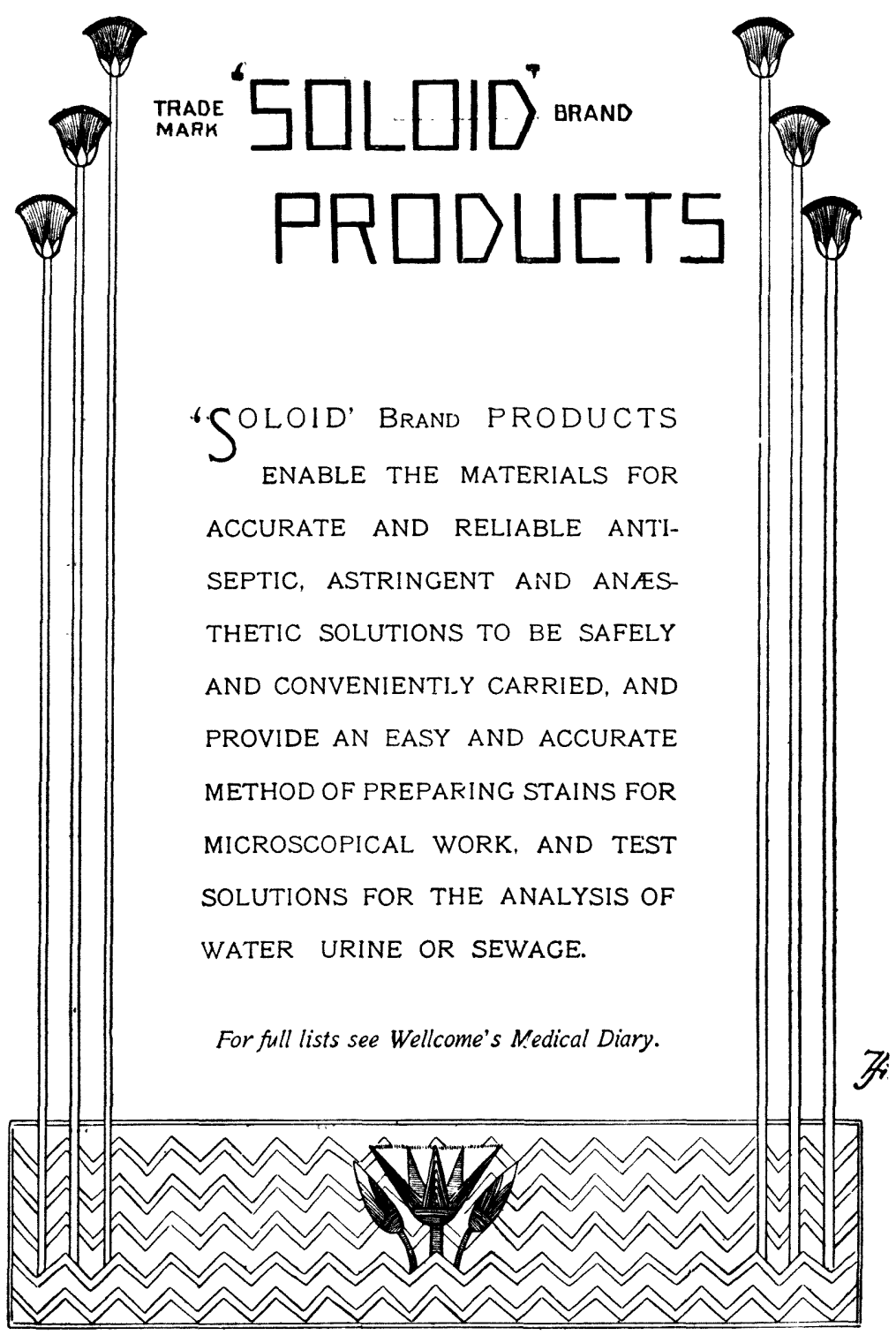

Burroughs Wellcome \& Co., london and sydney. [CONYRIGHT] 